Article

\title{
Antitumor Effect of the Mannich Base(1,3-bis- ((3-Hydroxynaphthalen-2-yl)phenylmethyl)urea) on Hepatocellular Carcinoma
}

\author{
Vadanasundari Vedarethinam ${ }^{1}$, Karthik Dhanaraj ${ }^{1}$, Soundharrajan Ilavenil ${ }^{2}$, \\ Mariadhas Valan Arasu ${ }^{3}$, Ki Choon Choi ${ }^{2}$, Naif Abdullah Al-Dhabi ${ }^{3}$, \\ Srigopalram Srisesharam ${ }^{2}$, Kyung Dong Lee ${ }^{4}$, Da Hye Kim ${ }^{5}$, Tamilvenvendan Dhanapal ${ }^{6}$, \\ Ravikumar Sivanesan ${ }^{1, *}$, Han Sung Choi ${ }^{7, *}$ and Young Ock Kim ${ }^{8, *}$ \\ 1 Department of Biotechnology, PRIST University, Thanjavur, Tamilnadu 613-403, India; \\ vedavadana@gmail.com (V.V.); kar07bio@gmail.com (K.D.) \\ 2 Grassland and Forage Division, National Institute of Animal Science, Chungnam 330-808, Korea; \\ arulvenil@rediffmail.com (S.I.); choiwh@Korea.kr (K.C.C.); srigopal.ram@gmail.com (S.S.) \\ 3 Department of Botany and Microbiology, Addiriyah Chair for Environmental Studies, College of Science, \\ King Saud University, Riyadh 11451, Saudi Arabia; mvalanarasu@gmail.com (M.V.A.); \\ naldhabi@ksu.edu.sa (N.A.A.-D.) \\ 4 Department of Oriental Medicine Materials, Dongshin University, Naju 520-714, Korea; leek-d@hanmail.net \\ 5 United Graduate School of Agricultural Sciences, Tottori University, Tottori 680-8550, Japan; \\ pioioiq@nate.com \\ 6 Department of Chemistry, National Institute of Technology, Tiruchirappalli 620-015, India; \\ haitamilvendan@gmail.com \\ 7 Department of Emergency Medicine, College of Medicine, Kyung Hee University, Seoul 02447, Korea \\ 8 Development of Ginseng and Medical Plants Research Institute, Rural Administration, \\ Eumseong 369-873, Korea \\ * Correspondence: drravinikesh@yahoo.co.in (R.S.); hsg3748@hanmail.net (H.S.C.); \\ kyo9128@korea.kr (Y.O.K.); Tel.: +91-9443724611 (R.S.); Fax: +91-4362 266150 (R.S.)
}

Academic Editor: Helena Vasconcelos

Received: 31 March 2016; Accepted: 4 May 2016; Published: 14 May 2016

\begin{abstract}
The present study was designed to evaluate the antitumor effects of the synthetic Mannich base 1,3-bis-((3-hydroxynaphthalen-2-yl)phenylmethyl)urea (1,3-BPMU) against HEP-G2 hepatoma cells and diethylnitrosamine (DEN)-induced hepatocarcinoma (HCC) in albino rats. In vitro analysis results revealed that 1,3-BPMU showed significant cytotoxicity and cell growth inhibition in HEP-G2 hepatoma cells in a concentration-dependent manner. Furthermore, flow cytometry results indicated that 1,3-BPMU enhanced early and late apoptosis. The maximum apoptosis was exhibited at a concentration of $100 \mu \mathrm{g} / \mathrm{mL}$ of 1,3-BPMU. In in vivo analysis, DEN treatment increased the content of nucleic acids, LPO and the activities of AST, ALT, ALP, LDH, $\gamma \mathrm{GT}$ and 5'NT with decreased antioxidant activity as compared to control rats. However, 1,3-BPMU treatment to DEN-induced rats decreased the content of nucleic acids, LPO and the activities of AST, ALT, ALP, LDH, $\gamma$ GT and $5^{\prime} \mathrm{NT}$ and increased the activities of SOD, CAT, GPx, GST and GR $(p<0.05)$. Furthermore, 1,3-BPMU enhanced the apoptosis via upregulation of caspase-3 and caspase-9 and the downregulation of Bcl-2 and Bcl-XL mRNA expression as compared to DEN-induced rats. Histological and ultrastructural investigation showed that 1,3-BPMU treatment renovated the internal architecture of the liver in DEN-induced rats. In this study, the molecular and pre-clinical results obtained by treatment of DEN-induced rats with 1,3-BPMU suggested that 1,3-BPMU might be considered as an antitumor compound in the future.
\end{abstract}

Keywords: 1,3-BPMU; HEP-G2 cells; DEN; apoptosis; ultrastructure 


\section{Introduction}

Hepatocellular carcinoma (HCC) is a primary liver cancer, the sixth most common malignant neoplasm, and 85\% of HCC patients die in developing countries [1,2]. Risk factors for HCC include hepatitis $B$ virus (HBV), hepatitis C virus (HCV), aflatoxins, alcohol and oral contraceptives [3], smoking, androgenic steroids and diabetes mellitus [4]. To trigger malignancy in different sites of the liver, numerous chemical carcinogen responses, which lead to varied patterns of cellular proliferation, occur in the development of HCC [5]. Carcinogenic substances are found in tobacco, meat, cosmetics, gasoline, many processed food items and alcoholic beverages [6]. Diethylnitrosamine, also known as N-nitrosodiethylamine (DEN), is extensively used as a carcinogen in the animal model. DEN is absorbed and metabolized by the pericentral zone and gets activated in the liver lobules. More activation leads to stimulated oxidative stress-mediated hepatocarcinogenesis through DNA damage by free radical formation, downregulated apoptotic genes and proteins, upregulated anti-apoptotic gene expression and protein synthesis [7].

Drug development and management are key techniques to develop new therapeutics to contest with HCC and to prolong patients' life. Synthesizing novel drugs for liver cancer by combinational organic synthesis is still challenging, and there is a keen interest in accelerating drug discovery [8,9]. Blocking the carcinogenic pathway and mechanism of HCC, novel drugs have been developed and discovered from artificial and natural sources [10,11]. Many such sources were identified as antioxidants; for example, galangin is one of the flavonoids from plants that stimulates apoptosis via the mitochondrial pathway and could be considered as a potential antitumor compound against HCC [12]. 2'-Fluoro-6,7-methylenedioxy-2-phenyl-4-quinolone is a synthetic 6,7-substituted 2-phenyl-4-quinolone used as a potent antitumor agent for human HCC [13].

Mannich bases possess potent antiviral, antibacterial, antifungal and antioxidant activity in in vitro models [14]. The chemoresistance of tumor cells is considered as the primary reason for chemotherapeutic treatment failure. The reasons for drug resistance in tumor cells includes low intracellular drug concentration, changes in drug target interaction and changes in the cellular response. Therefore, we need to identify novel compounds for the treatment of tumor cells, especially high drug-target interaction compounds. For that purpose, we synthesize Mannich base-derived lead compounds and analyzed their interaction with a sialoglyco protein (a protein increased in HCC) using computational biology tools [15]. According to our previous experiments, we planned to investigate the pre-clinical and molecular approaches for a newly-synthesized Mannich base-derived organic compound, namely 1,3-bis-((3-hydroxynaphthalen-2-yl)phenylmethyl)urea (1,3-BPMU) in HEP-G2 hepatoma cells and DEN-induced rats.

\section{Results}

\subsection{Cytotoxicity and Growth Inhibition Assay}

HEP-G2 hepatoma cells were incubated with different concentrations of 1,3-BPMU $(0.001,0.01$, $0.1,0.2$. $0.5,1,2,5,10,20,50$ and $100 \mu \mathrm{g} / \mathrm{mL})$ for $0.5,1,1.5,2$ and 3 days at $37{ }^{\circ} \mathrm{C}(p<0.05)$. The results showed that 1,3-BPMU treatment significantly reduced the HEP-G2 cell viability in a time- and dose-dependent manner. Maximum cytotoxic effects were noted at $100 \mu \mathrm{g} / \mathrm{mL}$ of $1,3-\mathrm{BPMU}$ (Figure 1A). Further, 1,3-BPMU treatment significantly inhibited the cell growth at concentrations of 50 and $100 \mu \mathrm{g} / \mathrm{mL}$ of 1,3-BPMU (Figure 1B).

\subsection{Flow Cytometry Analysis}

Figure $2 \mathrm{~A}-\mathrm{K}$ shows the percentage of apoptosis and necrosis in experimental cells. The results clearly indicated that 1,3-BPMU treatment significantly increased cellular necrosis, late apoptosis and early apoptosis in HEP-G2 cells in a dose-dependent manner. The maximum necrosis $(0.5 \%)$, late apoptosis (79.6\%) and early apoptosis (19.3\%) were noted at the concentration of $100 \mu \mathrm{g} / \mathrm{mL}(p<0.05)$. 

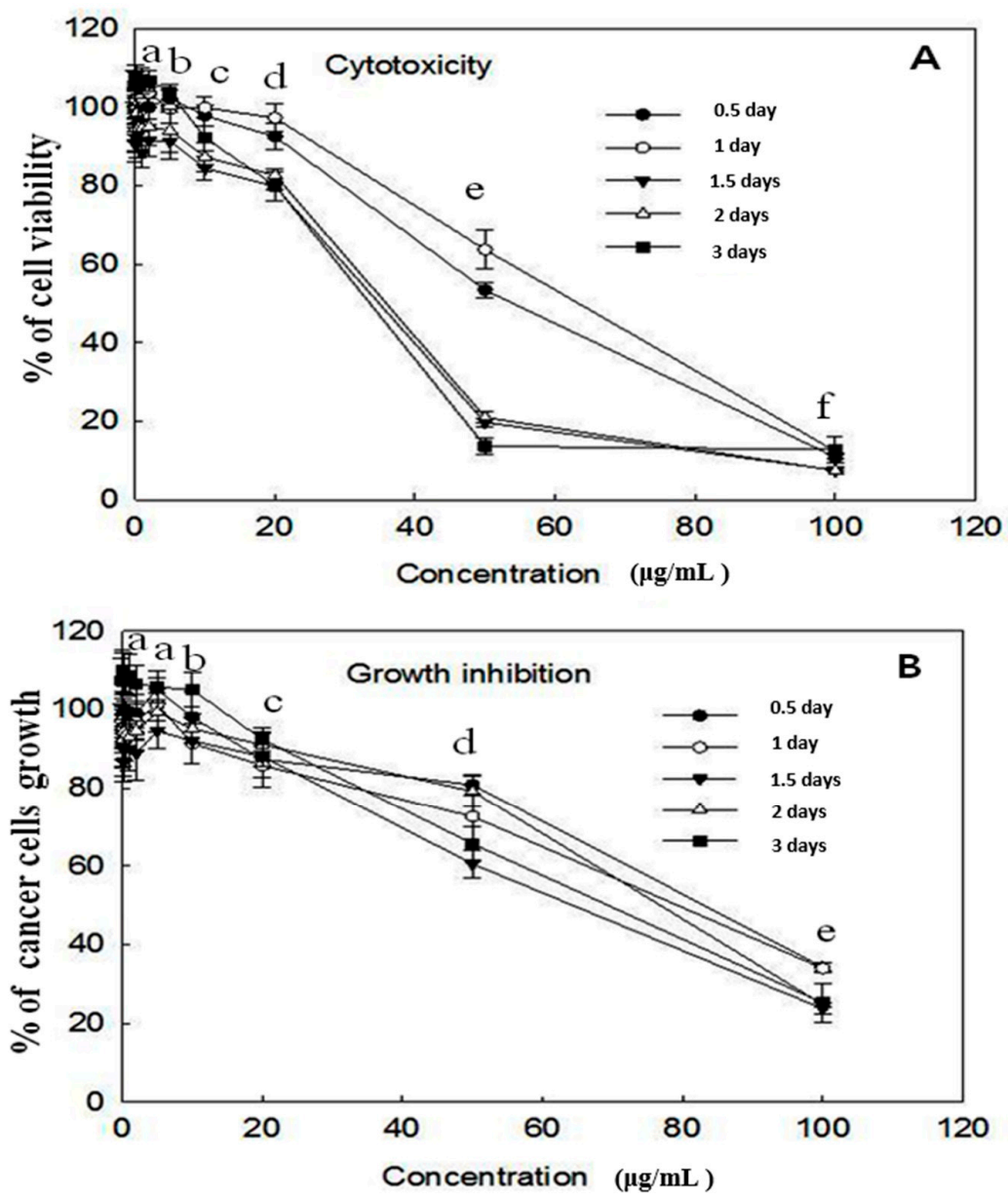

Figure 1. (A) Cytotoxicity effect of 1,3-BPMU on HEP-G2 hepatoma cells. The cells were treated with different concentrations of 1,3-BPMU in 10\% FBS-DMEM and incubated for 0.5, 1.0, 1.5, 2.0 and 3 days at $37^{\circ} \mathrm{C}$. The maximum cytotoxicity was exhibited at the concentrations of 50 and $100 \mu \mathrm{g} / \mathrm{mL}$ of 1,3-BPMU; (B) Effect of 1,3-BPMU on HEP-G2 cell growth. The cells were treated with different concentrations of 1,3-BPMU in serum-free DMEM and incubated for 0.5, 1.0, 1.5, 2.0 and 3 days at $37^{\circ} \mathrm{C}$. 1,3-BPMU exhibited a potent tumor growth inhibition at $100 \mu \mathrm{g} / \mathrm{mL}$. Different letters, a, b, c, d, e, f, within a treatment between concentrations of 1,3-BPMU indicate significant differences $(p<0.05)$.

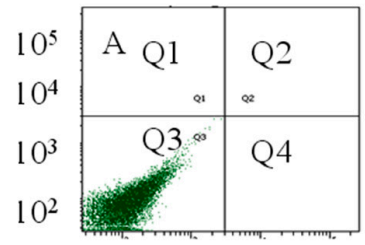

$\begin{array}{llll}10^{2} & 10^{3} & 10^{4} & 10^{5}\end{array}$

Q1: Necrosis

Q2: Late apoptosis

Q4: Early apoptosis
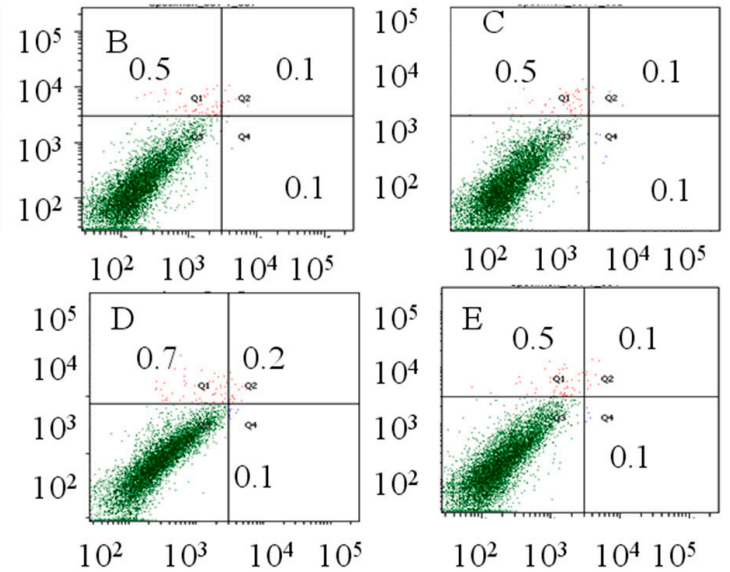

$\begin{array}{llll}10^{2} & 10^{3} & 10^{4} & 10^{5}\end{array}$

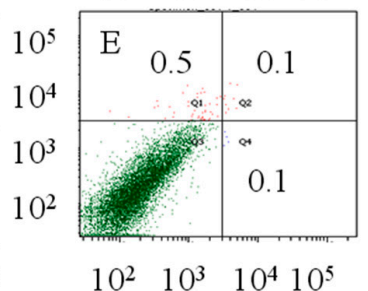

Figure 2. Cont. 


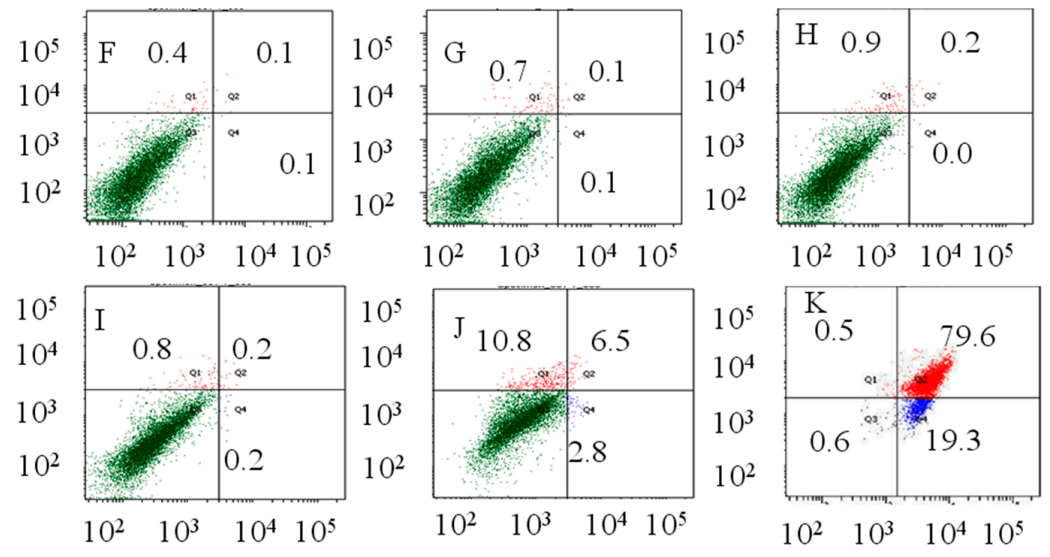

Figure 2. Apoptosis and necrosis quantification. (A) Control; (B) 0.1 ; (C) 0.2 ; (D) 0.5 ; (E) 1.0 ; (F) 2.0; (G) 5.0; (H) 10; (I) 20; (J) 50; (K) $100 \mu \mathrm{g} / \mathrm{mL}$ of 1,3-BPMU.

\subsection{Growth Conditions of the Rats}

The normal rats excreted normal urine and gained significant amounts of body weight with healthy activity and good hair. Tumor-bearing rats exhibited poor health conditions, including lack of activity, loss of hair, lack of feed intake and slow growth. The body and liver weights of experimental rats are given in Table 1 . The final body weight of tumor-bearing rats was significantly lower than the normal rats $(p<0.05)$. The 1,3-BPMU treatment of cancer-induced rats increased their body weight as compared to tumor control rats $(p<0.05)$ However, rats treated with 1,3-BPMU showed significantly reduced liver weight as compared to tumor-bearing rats. There were no significant alterations observed in rats treated with 1,3-BPMU alone as compared to control rats $(p<0.05)$.

Table 1. Body and liver weight of control and experimental rats.

\begin{tabular}{ccccc}
\hline Body Weight (g) & Control & 1,3-BPMU Alone & Tumor Control & DEN + 1,3-BPMU * \\
\hline Initial & $156 \pm 10.21^{\mathrm{a}}$ & $162 \pm 12.8^{\mathrm{a}}$ & $157 \pm 12.9^{\mathrm{b}}$ & $159^{\mathrm{a}} \pm 12.5^{\mathrm{c}}$ \\
Final & $202 \pm 11.20^{\mathrm{a}}$ & $205 \pm 9.20^{\mathrm{a}}$ & $184 \pm 11.8^{\mathrm{b}}$ & $208 \pm 10.8^{\mathrm{c}}$ \\
Liver & $7.45 \pm 0.59^{\mathrm{a}}$ & $8.20 \pm 0.65^{\mathrm{a}}$ & $13.29 \pm 1.2^{\mathrm{b}}$ & $8.32^{ \pm} \pm .67^{\mathrm{c}}$ \\
\hline
\end{tabular}

The results are expressed as the mean \pm SD for six rats in each group. ${ }^{\mathrm{b}} p<0.05$ as compared to normal control and 1,3-BPMU alone rats ${ }^{\mathrm{a}} ;{ }^{\mathrm{c}} p<0.05$ as compared to tumor control rats. ${ }^{*} 1,3-\mathrm{BPMU} 50 \mathrm{mg} / \mathrm{kg} / \mathrm{bw} /$ day /orally and DEN $200 \mathrm{mg} / \mathrm{kg} / \mathrm{bw} / \mathrm{ip}$.

\subsection{Inhibitory Effect of 1,3-BPMU on Tumor Growth in DEN-Induced Rats}

Numerous visible nodules were found in tumor-bearing rats and 1,3-BPMU with DEN-induced rats. Tumor-bearing rats had more large- and small-sized nodules $(58.65 \pm 1.02$ nodules $(>2 \mathrm{~mm}$ size) and $6.3 \pm 0.05$ nodules $(>4 \mathrm{~mm}))$. 1,3-BPMU treatment of the cancer-bearing rats significantly reduced the number of nodules as compared to tumor-bearing rats $(p<0.05)$. The mean volume of nodules in the 1,3-BPMU treatment of cancer-bearing rats was less than in tumor-bearing rats (Table 2).

Table 2. Effect of 1,3-BPMU on hepatocarcinoma incidence.

\begin{tabular}{|c|c|c|c|}
\hline \multirow{2}{*}{ Groups } & \multicolumn{2}{|c|}{ Average Number of Nodules in Liver } & \multirow{2}{*}{ Volume of Nodules $\left(\mathrm{mm}^{3}\right)$} \\
\hline & $(>2 \mathrm{~mm})$ & $(>4 \mathrm{~mm})$ & \\
\hline Normal control & $0^{\mathrm{a}}$ & $0^{\mathrm{a}}$ & $0^{\mathrm{a}}$ \\
\hline Tumor control & $58.65 \pm 1.02^{b}$ & $6.3 \pm 0.05^{b}$ & $192.55 \pm 2.85^{b}$ \\
\hline $\mathrm{DEN}+1,3-\mathrm{BPMU}$ * & $34.21 \pm 0.98^{c}$ & $2.6 \pm 0.03^{c}$ & $72.25 \pm 0.24^{c}$ \\
\hline
\end{tabular}

The results are expressed as the mean \pm SD for six rats in each group. ${ }^{b} p<0.05$ as compared to normal control and 1,3-BPMU alone rats ${ }^{\mathrm{a}}{ }^{\mathrm{c}}{ }^{\mathrm{p}} p<0.05$ as compared to tumor control rats. ${ }^{*} 1,3-\mathrm{BPMU} 50 \mathrm{mg} / \mathrm{kg} / \mathrm{bw} / \mathrm{day} / \mathrm{orally}$ and DEN $200 \mathrm{mg} / \mathrm{kg} / \mathrm{bw} / \mathrm{ip}$. 


\subsection{Estimation of DNA and RNA}

Table 3 represents the quantification of DNA and RNA levels in the experimental groups of rats. The levels of DNA and RNA were increased in tumor-bearing rats as compared to normal rats, whereas cancer-bearing rats treated with 1,3-BPMU exhibit reduced levels of DNA and RNA as compared to tumor control rats. The elevation of DNA levels is associated with malignancy development. This indicates the cell proliferation activity under tumor conditions. There were no significant changes observed in rats treated with 1,3-BPMU alone as compared to normal rats.

Table 3. Effect of 1,3-BPMU on the levels of nucleic acids in livers of control and experimental groups of rats.

\begin{tabular}{ccccc}
\hline $\begin{array}{c}\text { Nucleic Acids } \\
\text { (mg/g Wet Tissue) }\end{array}$ & Normal Control & 1,3-BPMU Alone & Tumor Control & DEN + 1,3-BPMU * \\
\hline DNA & $1.8 \pm 0.04^{\mathrm{a}}$ & $5.72 \pm 0.14^{\mathrm{a}}$ & $8.10 \pm 0.08^{\mathrm{b}}$ & $2.28 \pm 0.13^{\mathrm{c}}$ \\
RNA & $1.3 \pm 0.09^{\mathrm{a}}$ & $2.70 \pm 0.07^{\mathrm{a}}$ & $5.3 \pm 0.20^{\mathrm{b}}$ & $1.58 \pm 0.08^{\mathrm{c}}$ \\
\hline
\end{tabular}

The results are expressed as the mean \pm SD for six rats in each group. ${ }^{\mathrm{b}} p<0.05$ as compared to normal control and 1,3-BPMU alone rats ${ }^{\text {a }}$; $p<0.05$ as compared to tumor control rats. ${ }^{*} 1,3-$ BPMU $50 \mathrm{mg} / \mathrm{kg} / \mathrm{bw} /$ day $/$ orally and DEN $200 \mathrm{mg} / \mathrm{kg} / \mathrm{bw} / \mathrm{ip}$.

\subsection{Estimation of Tumor Markers (AFP and CEA) Concentration}

Table 4 shows tumor marker proteins, such as $\alpha$-fetoprotein (AFP) and carcinoembryonic antigen (CEA), in the experimental groups of rats. The levels of AFP and CEA cancer markers were elevated in tumor rats as compared to normal control $(p<0.05)$. However, 1,3-BPMU treatment significantly reduced the tumor marker levels in tumor rats as compared to tumor control rats $(p<0.05)$. There were no significant variations observed in rats treated with 1,3-BPMU alone as compared to normal rats.

Table 4. Effects of 1,3-BPMU on cancer marker proteins $\alpha$-fetoprotein and carcinoembryonic antigen in control and experimental groups of rats.

\begin{tabular}{ccc}
\hline Groups & AFP $(\mathbf{n g} / \mathbf{m L})$ & CEA (ng/mL) \\
\hline Normal control & $0.05 \pm 0.003^{\mathrm{a}}$ & $0.04 \pm 0.003^{\mathrm{a}}$ \\
1,3-BPMU alone & $0.05 \pm 0.004^{\mathrm{a}}$ & $0.03 \pm 0.005^{\mathrm{a}}$ \\
Tumor control & $1.58 \pm 0.07^{\mathrm{b}}$ & $2.47 \pm 0.050^{\mathrm{b}}$ \\
DEN + 1,3-BPMU * & $0.43 \pm 0.05^{\mathrm{c}}$ & $0.18 \pm 0.090^{\mathrm{c}}$ \\
\hline
\end{tabular}

The results are expressed as the mean \pm SD for six rats in each group. ${ }^{\mathrm{b}} p<0.05$ as compared to normal control and 1,3-BPMU alone rats ${ }^{\mathrm{a}}{ }^{\mathrm{c}} p<0.05$ as compared to tumor control rats. ${ }^{*} 1,3-\mathrm{BPMU} 50 \mathrm{mg} / \mathrm{kg} / \mathrm{bw} /$ day /orally and DEN $200 \mathrm{mg} / \mathrm{kg} / \mathrm{bw} / \mathrm{ip}$.

\subsection{Activities of Serum Marker Enzymes, Lipid Peroxidation and Antioxidant Status}

Table 5 shows the AST, ALT and ALP, LDH, $\gamma$ GT and $5^{\prime} \mathrm{NT}$ activities in experimental rats. Tumor control rats showed increased activities of AST, ALT, ALP, LDH, $\gamma$ GT and 5'NT as compared to normal rats, whereas, cancer-bearing rats treated with 1,3-BPMU showed a significant reduction in AST, ALT, ALP, LDH, $\gamma \mathrm{GT}$ and $5^{\prime} \mathrm{NT}$ activities as compared to tumor rats $(p<0.05)$. Rats treated with 1,3-BPMU alone did not exhibit significant changes in AST, ALT, ALP, LDH, $\gamma \mathrm{GT}$ and $5^{\prime} \mathrm{NT}$ activities as compared to normal rats.

The effects of 1,3-BPMU on lipid peroxide (LPO) and antioxidant status in the experimental group of rats are shown in Table 6. The LPO level was increased in tumor control animals as compared to normal rats $(p<0.05)$. DEN-induced rats administered with 1,3-BPMU showed a significant reduction of LPO levels. The antioxidant enzymes, such as SOD, CAT, GPx GR and GST, were reduced in tumor-bearing rats $(p<0.05)$. However, cancer-induced rats treated with 1,3-BPMU had reversed antioxidant status as compared to tumor-bearing rats $(p<0.05)$. No significant changes were noted in rats treated with 1,3-BPMU alone as compared to normal rats. 
Table 5. Effects of 1,3-BPMU on serum marker enzymes of control and experimental rat groups.

\begin{tabular}{ccccccc}
\hline Groups & AST (U/L) & ALT (U/L) & ALP (U/L) & LDH (U/L) & $\gamma$ GT (U/L) & $5^{\prime}$ NT (U/L) \\
\hline Normal control & $44.0 \pm 2.42^{\mathrm{a}}$ & $27.08 \pm 1.08^{\mathrm{a}}$ & $33.17 \pm 1.21^{\mathrm{a}}$ & $5.9 \pm 0.36^{\mathrm{a}}$ & $6.09 \pm 0.32^{\mathrm{a}}$ & $3.08 \pm 0.38^{\mathrm{a}}$ \\
1,3-BPMU alone & $43.0 \pm 1.63^{\mathrm{a}}$ & $26.05 \pm 1.11^{\mathrm{a}}$ & $34.12 \pm 1.12^{\mathrm{a}}$ & $5.6 \pm 0.35^{\mathrm{a}}$ & $6.08 \pm 0.33^{\mathrm{a}}$ & $3.0 \pm 0.38^{\mathrm{a}}$ \\
Tumor control & $192.2 \pm 2.03^{\mathrm{b}}$ & $82.36 \pm 1.67^{\mathrm{b}}$ & $75.46 \pm 1.39^{\mathrm{b}}$ & $12.3 \pm 0.30^{\mathrm{b}}$ & $12.38 \pm 1.05^{\mathrm{b}}$ & $6.19 \pm 0.78^{\mathrm{b}}$ \\
DEN + 1,3-BPMU * & $98.2 \pm 3.79^{\mathrm{c}}$ & $36.04 \pm 1.33^{\mathrm{c}}$ & $34.23 \pm 1.99^{\mathrm{c}}$ & $8.1 \pm 0.24^{\mathrm{c}}$ & $5.13 \pm 0.46^{\mathrm{c}}$ & $4.38 \pm 0.51^{\mathrm{c}}$ \\
\hline
\end{tabular}

The results are expressed as the mean \pm SD for six rats in each group. ${ }^{\mathrm{b}} p<0.05$ as compared to normal control and 1,3-BPMU alone rats ${ }^{\mathrm{a}} ;{ }^{\mathrm{c}} p<0.05$ as compared to tumor control rats. ${ }^{*} 1,3-\mathrm{BPMU} 50 \mathrm{mg} / \mathrm{kg} / \mathrm{bw} /$ day/orally and DEN $200 \mathrm{mg} / \mathrm{kg} / \mathrm{bw} / \mathrm{ip}$.

Table 6. Effect of 1,3-BPMU on lipid peroxidation and antioxidant status of control and experimental groups of rats.

\begin{tabular}{ccccccc}
\hline Groups & LPO & SOD (U/mg) & CAT (U/mg) & GPx (U/mg) & GR (U/mg) & GST (U/mg) \\
\hline Normal control & $2.97 \pm 0.11^{\mathrm{a}}$ & $3.99 \pm 0.19^{\mathrm{a}}$ & $4.82 \pm 0.23^{\mathrm{a}}$ & $6.21 \pm 0.43^{\mathrm{a}}$ & $5.28 \pm 0.26^{\mathrm{a}}$ & $0.89 \pm 0.02^{\mathrm{a}}$ \\
$1,3-B P M U$ alone & $2.42 \pm 1.16^{\mathrm{a}}$ & $4.35 \pm 0.21^{\mathrm{a}}$ & $4.61 \pm 0.22^{\mathrm{a}}$ & $6.72 \pm 0.33^{\mathrm{a}}$ & $5.63 \pm 0.28^{\mathrm{a}}$ & $0.96 \pm 0.02^{\mathrm{a}}$ \\
Tumor control & $3.96 \pm 0.19^{\mathrm{b}}$ & $2.56 \pm 0.27^{\mathrm{b}}$ & $3.88 \pm 0.28^{\mathrm{b}}$ & $2.63 \pm 0.38^{\mathrm{b}}$ & $3.82 \pm 0.19^{\mathrm{b}}$ & $0.59 \pm 0.01^{\mathrm{b}}$ \\
DEN + 1,3-BPMU * & $2.99 \pm 0.14^{\mathrm{c}}$ & $4.87 \pm 0.24^{\mathrm{c}}$ & $4.72 \pm 0.24^{\mathrm{c}}$ & $5.73 \pm 0.33^{\mathrm{c}}$ & $4.83 \pm 0.24^{\mathrm{c}}$ & $0.71 \pm 0.02^{\mathrm{c}}$ \\
\hline
\end{tabular}

LPO U/mg of protein; activity is expressed as $\mu \mathrm{mol}$ of GSH oxidized per min per mg of protein for GPx; units per min per mg of protein for GST; $50 \%$ inhibition of epinephrine auto-oxidation for SOD; $\mu$ mole of hydrogen peroxide decomposed per min per $\mathrm{mg}$ of protein for CAT and $\mu$ mole of NADPH oxidized $/(\mathrm{min} / \mathrm{mg}$ protein) for GR. The results are expressed as the mean $\pm \mathrm{SD}$ for six rats in each group. ${ }^{\mathrm{b}} p<0.05$ as compared to normal control and 1,3-BPMU alone rats ${ }^{\mathrm{a}} ;{ }^{\mathrm{c}} p<0.05$ as compared to tumor control rats. ${ }^{*} 1,3-\mathrm{BPMU} 50$ $\mathrm{mg} / \mathrm{kg} / \mathrm{bw} /$ day/orally and DEN $200 \mathrm{mg} / \mathrm{kg} / \mathrm{bw} / \mathrm{ip}$.

\subsection{Apoptotic and Anti-Apoptotic Gene Expression Analysis by $q P C R$}

Figure 3A shows apoptotic and anti-apoptotic gene expression in the liver of experimental animals. The expression of apoptotic genes, such as caspase-3 and caspase-9, was decreased in tumor-bearing rats as compared to the normal control rats, whereas DEN-induced rats treated with 1,3-BPMU displayed significantly increased caspase-3 and caspase-9 expression as compared to the tumor-bearing rats. The anti-apoptotic genes, such as Bcl-2 and Bcl-XL, increased their expression in tumor-bearing rats as compared to normal rats, whereas tumor-bearing rats treated with 1,3-BPMU had downregulated Bcl-2 and Bcl-XL expressions as compared to tumor-bearing rats. Figure 3B shows colorimetric quantification of caspse-3 expressions in experimental rats. The caspase-3 protein level was decreased in tumor-bearing rats as compared to normal rats, whereas 1,3-BPMU treatment of DEN-induced rats showed increased capase-3 expression as compared to tumor-bearing rats.

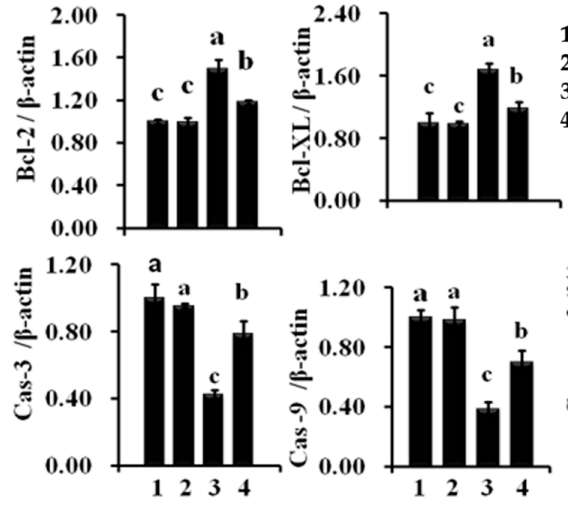

$\mathbf{A}$
1. Control

2. 1,3-BPMU alone

. Tumor control

4. DEN + 1,3-BPMU

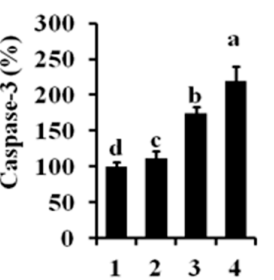

B

Figure 3. Impact of 1,3-BPMU on apoptotic and anti-apoptotic gene expression in control and experimental animals. (A) Bcl-2, Bcl-XL, caspase-3 and caspase 9 mRNA expression in experimental rats; (B) Quantification of caspse-3 protein expression in experimental rats. Different letters, a, b, c, d, within a treatment between concentrations of 1,3-BPMU indicate significant differences $(p<0.05)$. 


\subsection{Histology and Ultrastructural Study}

Figure 4 shows histological observations of liver sections of experimental rats. The numbers of visible nodules were higher in the tumor-bearing rats than 1,3-BPMU-treated rats. The normal rats exhibited normal architecture, central vein, normal size of hepatocyte with the proper nucleus and granulated cytoplasm. The tumor-bearing rats exhibited an unformatted architecture, enlarged nuclear size and more inflammatory cells around the central vein. The cancer-bearing rats treated with 1,3-BPMU significantly reverted to the normal structure of liver as compared to tumor-bearing rats.

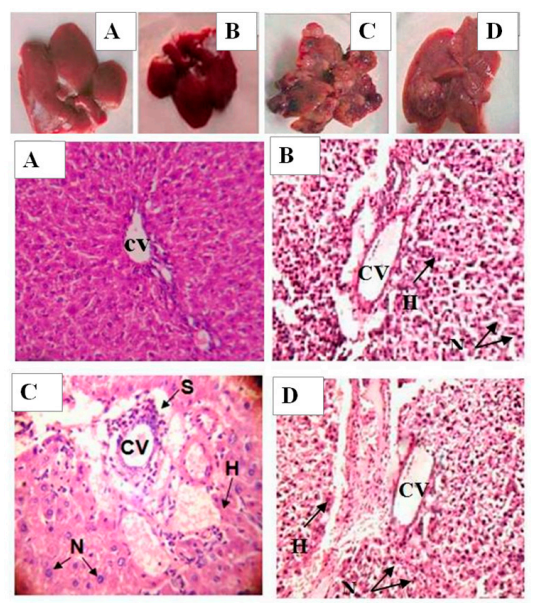

Figure 4. Histological analysis of liver tissue by hematoxylin-eosin staining. (A) Normal rats; (B) 1,3-BPMU alone; (C) tumor control; (D) DEN + 1,3-BPMU rats. Sinusoids (S), nucleus (N), central vein $(\mathrm{CV})$ and hepatocyte $(\mathrm{H})$.

The ultra-structural changes that occurred in hepatocytes of experimental rats are shown in Figure 5. Electron micrographs of the hepatocytes of normal rats showed intact cellular organelles, mitochondria, a nucleus with a nuclear membrane and a rough endoplasmic reticulum. A similar architecture was observed in rats that were treated with 1,3-BPMU alone. Tumor-bearing rats showed damaged intracellular organelles, with an unshaped nucleus and improper cytoplasm and mitochondria arrangement, as well as numerous mitochondria of abnormal size. The cancer rats treated with 1,3-BPMU showed significantly restored nuclear and mitochondrial size and shape. This indicates that 1,3-BPMU has the ability to prevent cancer induced by DEN.
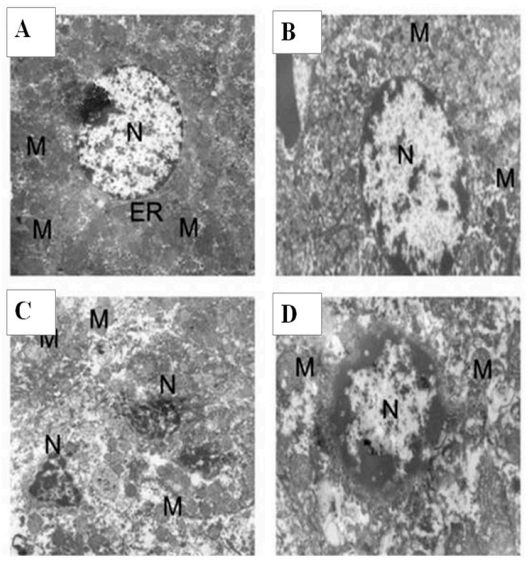

Figure 5. Ultrastructural analysis of liver tissue by transmission electron microscope (TEM). (A) Normal rats; (B) 1,3-BPMU alone; (C) tumor control; (D) DEN + 1,3-BPMU rats. Mitochondria (M), endoplasmic reticulum (ER) and nucleus $(\mathrm{N})$. 


\section{Discussion}

The liver plays a pivotal role in the regulation of physiological processes. Due to oxidative stress, macromolecules, such as lipids, proteins and other molecules, get disturbed. In this study, initially, we evaluated the cytotoxicity and growth inhibition ability of 1,3-BPMU in HEP-G2 hepatoma cells. The activation of cell cycle control proteins is a major mechanism for many DNA-damaging agents, including irradiation, and most antitumor compounds used in the clinic that stimulate DNA damage [16]. The maximum cytotoxicity effects were observed at a concentration of $100 \mu \mathrm{g} / \mathrm{mL}$ on the third day. Further, 1,3-BPMU significantly inhibits the cell growth at 50 and $100 \mu \mathrm{g} / \mathrm{mL}$ by the third day of incubation. The cell cycle progress is an important indicator of the molecular mechanism of cell death and cell cycle progression [17]. Flow cytometry analysis is used to find out the apoptotic alteration in the cells [18]. The apoptotic effect of 1,3-BPMU was examined by flow cytometer (FITC-annexin-V), and the results revealed that maximum $(0.5 \%)$, late apoptosis $(79.6 \%)$ and early apoptosis $(19.3 \%)$ were noted at the concentration of $100 \mu \mathrm{g} / \mathrm{mL}$ of 1,3-BPMU. These results suggested that 1,3-BPMU extensively induced apoptosis in HEP-G2 hepatoma cells with an increase of incubation time.

Generally, carcinogens stimulate the formation of free radical and non-radical oxidizing species in animals and humans in pathologic environments [19]. DNA acts as a genetic determinant and functional aspect of all tumor formations. In our present study, DNA and RNA synthesis were elevated in experimental groups because nucleic acids are involved in multiple functions, such as cell division and cell differentiation, etc. Uncontrolled cell division and cell differentiation lead to tumor progress. We noted increased DNA and RNA levels in cancer-bearing rats, which indicates that the DEN treatment increased the replication and transcription process in rats. However, 1,3-BPMU treatment of cancer-bearing animals reduced nucleic acid biosynthesis; this indicated that 1,3-BPMU can control cancer cell growth through inhibition of nucleic acids synthesis. Furthermore, 1,3-BPMU treatment of the cancer-bearing rats showed reduced numbers of nodules and tumor volume. This result strongly correlated with nucleic acid level, body and liver weight of rats in the 1,3-BPMU-treated group.

The carcinoembryonic antigen (CEA) is one of the immunoglobulin supergene families used to detect tumors by its functions, such as adhesion, forming homotypic and heterotypic aggregates between the cells [20]. $\alpha$-Fetoprotein is another oncofetal glycoprotein. It is not found in normal healthy people. It is the best marker for the detection of HCC. AFP along with CEA are widely used in the diagnosis of HCC [21-23]. In the present study, high levels of AFP and CEA were noted in the DEN-induced rats. This confirmed the development of HCC in rats. However, treatment of cancer-bearing rats with 1,3-BPMU significantly decreased the level of AFP and CEA as compared to tumor rats.

Administration of 1,3-BPMU to the DEN-induced rats improved the metabolic function of the liver by decreasing the liver marker level in cancer-bearing rats. The activities of AST and ALT will increase with the incidence of hepatic diseases and abnormal metabolic function. AST is an enzyme found in the liver, heart, skeletal muscles, kidneys and, to a lesser extent, in the pancreas [24]. An increase of these markers is usually associated with cardiac arrest or liver disease. Furthermore, ALP, LDH and $\gamma$ GT activities were increased in cancer-bearing rats, which indicated the abnormal metabolism of hepatic cells. ALT and AST increases lead to the development of hepatocellular damage. In our study, we noted increased levels of ALT and AST in cancer-bearing rats. This is great evidence for cancer development in rats caused by the DEN treatment. However, cancer-bearing rats treated with 1,3-BPMU significantly normalized the elevated levels of ALT and AST. The leakage of LDH indicates non-specific changes in plasma membrane integrity. Liberation of $\gamma$ GT present in the plasma membrane into serum indicates liver cell damage. In the present study, cancer-bearing rats showed higher levels of LDH and $\gamma$ GT in the blood, which indicates that DEN disturbed the integrity of the plasma membrane. The 1,3-BPMU treatment of cancer-bearing rats significantly reduced the level of these enzymes as compared to tumor rats, confirming that 1,3-BPMU maintains the membrane integrity of the liver. Liver marker enzyme $5^{\prime} \mathrm{NT}$ is present on the surface of the plasma membrane of hepatocytes and acts as a tool for the diagnosis of liver injury [25-27]. Elevated levels of the $5^{\prime} \mathrm{NT}$ 
marker enzyme in tumor rats are correlated with malignancy development. 1,3-BPMU treatment decreased the activity of $5^{\prime} \mathrm{NT}$ as compared to tumor rats.

Lipid peroxides play an important role in carcinogenesis and cellular injury. In general, DEN administration generates LPO, like MDA, that may stimulate oxidative stress and carcinogenesis. The highest level of LPO is noted during cancerous conditions in the rats. The activity of LPO leads to the uncompromised production of free radicals that overcome the cellular antioxidant defenses [28-31]. The present study exhibited increased levels of LPO in tumor rats as compared to normal rats. However, 1,3-BPMU-treated rats showed reduced levels of LPO as compared to tumor control rats. This indicates 1,3-BPMU controls the free radical generation in the cancer-bearing rats.

Antioxidant enzymes play a major role in protecting the cell from various compounds, like reactive oxygen species (ROS) and chemical carcinogens. SOD, CAT, GPx, GST and GR play the main role in the elimination of ROS [32,33]. Superoxide dismutase is involved in the scavenging of superoxide radicals, and it acts as the first line of defense against superoxide phosphorylation. In the present study, decreased activities of antioxidant enzymes, such as SOD, CAT, GPx, GST and GR, were observed in cancer-bearing rats, which indicates that DEN-induced oxidative stress leads to HCC. The 1,3-BPMU treatment of cancer-bearing rats significantly improves the antioxidant status as compared to untreated cancer-bearing rats. The results indicated that administration of 1,3-BPMU helps to restore the hepatic cellular function through a free radical scavenging mechanism.

Caspases are groups of aspartate-specific cysteine proteases that regulate the apoptosis induced by different kinds of stimuli. Caspase- 3 is an effector gene involved in the apoptotic process, and caspase- 9 acts as an initiator of caspase- 3 in the mitochondria-dependent pathway. Generally, the caspases regulate apoptosis through DNA fragmentation, chromatin condensation and nuclear fragmentation. Caspase- 3 activation could be caused by upstream proteases, either caspase- 3 in the intrinsic pathway or caspase-8 in the extrinsic pathway in the death receptors [34]. In the present study, cancer-bearing rats showed reduced expression of caspse- 3 and caspase- 9 as compared to normal control rats. This indicates that DEN injection blocks the apoptosis program through downregulation of caspase- 3 and caspse-9, but cancer-bearing rats administered with 1,3-BPMU show significantly increased caspase-3 and caspse- 9 expression. This upregulation of these genes enhances the apoptotic process. Bcl-2 genes are important regulators for cytochrome $\mathrm{C}$ release from mitochondria and caspases activation. These groups contain both apoptotic and antiapoptotic genes. Bcl-XL expressions prevent mitochondrial cytochrome $\mathrm{C}$ release, protecting the cells from apoptosis by inhibiting the availability of cytochrome $\mathrm{C}$ in the cytosol [35]. In our study, DEN treatments upregulated the Bcl-2 and Bcl-XL mRNA transcripts in liver of rats as compared to normal rats. Results confirmed that DEN treatment induced cell proliferation and inhibits cell apoptosis in rats. Increased cell proliferation and inhibition of cell apoptosis cause tumor and cancer, whereas in cancer-bearing rats treated with 1,3-BPMU, Bcl-2 and $\mathrm{Bcl}-\mathrm{XL}$ mRNA transcripts were significantly downregulated as compared to cancer-bearing rats. From these results, it is concluded that 1,3-BPMU significantly activates the apoptotic process through upregulation of apoptotic genes and downregulation of anti-apoptotic genes. Previously, we analyzed the effect of 1,3-BPMU on protein expression changes in DEN-induced rats. That confirmed that 1,3-BPMU regulates numerous proteins associated with cancer prevention mechanisms in rats [36].

Histopathological and transmission electron microscopic investigations were performed to evidence morphological changes in experimental rats. H \& E-stained normal liver tissue showed normal architecture arrangement and the normal size of hepatocytes with the nucleus and granulated cytoplasm. The cancer-bearing rats exhibited an unformatted architecture, enlarged nuclear size and more inflammatory cells around the central vein. The cancer-bearing rats treated with 1,3-BPMU significantly reversed to a normal liver structure as compared to cancer rats. TEM results showed that cancer-bearing rats exhibited irregularly-shaped nucleus and cytoplasm; metastatic stages were seen, which might be due to the excessive free radical generation. Normal and 1,3-BPMU alone-treated rats exhibited a similar kind of architecture; cancer-bearing rats treated with 1,3-BPMU show signs of the stimulation of apoptosis, like shrunken nucleus, condensed chromatin membrane and the formation 
of apoptotic bodies. This indicates that administration of 1,3-BPMU restores the hepatic cellular architecture and hepatic cellular function through the apoptotic mechanism. All of the biochemical results significantly correlated with the histological studies.

\section{Materials and Methods}

\subsection{Chemicals}

Diethylnitrosamine (DEN) and phenobarbital were obtained from Sigma Aldrich (St Louis, MO, USA), and the remaining chemicals used in this study were of analytical grade. Human HEP-G2 hepatoma cells (ATCC-HB-8065) were procured from the American Type Culture Collection (ATCC, Manassas, VA, USA).

\subsection{Synthesis of Mannich Base}

Formulation and characterization of 1,3-BPMU were carried out by Dr. Tamilvendan Dhanapal at the National Institute of Technology (Trichy, India) according to Scheme 1 [14].

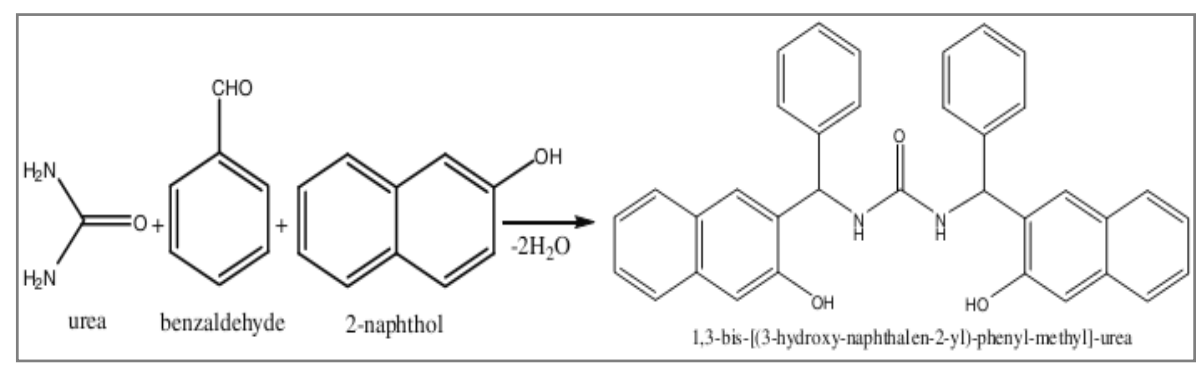

Scheme 1. Reaction scheme for 1,3-bis-[(3-hydroxynaphthalen-2-yl) phenylmethyl]urea.

\subsection{Cytotoxicity and Growth Inhibition Assay}

Cell toxicity was assessed by the MTT assay. Briefly, HEP-G2 hepatoma cells were maintained in DMEM culture medium supplemented with $10 \% \mathrm{FBS}$ at $5 \% \mathrm{CO}_{2}$ at $37{ }^{\circ} \mathrm{C}$ and sub-cultured in 96 wells containing serum-free media (SFM) at a density of $3 \times 10^{4}$ cells/well, exposed to different concentrations of 1,3-BPMU (0.001, 0.01, 0.1, 0.2 0.5, 1, 2, 5, 10, 20, 50 and $100 \mu \mathrm{g} / \mathrm{mL})$ for 0.5, 1, 1.5, 2 and 3 days at $37^{\circ} \mathrm{C}$. Then, the cells were treated with MTT reagent and placed into a $\% \mathrm{CO}_{2}$ incubator at $37^{\circ} \mathrm{C}$ for $4 \mathrm{~h}$ [37]. The growth inhibitory effect of 1,3-BPMU was studied as follows: $5 \times 10^{3}$ HEP-G2 hepatoma cells seeded in 96-well plates with $100-\mu \mathrm{L}$ volumes of growth media. Then, the cells were treated with different concentrations of 1,3-BPMU in DMEM media supplemented with $10 \%$ serum. The absorbance was measured at $560 \mathrm{~nm}$.

\subsection{Flow Cytometric Analysis of Apoptosis}

FITC-annexin V (sc-4252 FITC, Santa Cruz biotechnology, Santa Cruz, CA, USA) was used for analyzing the apoptosis, and propidium iodide (PI) reagent (P4170, Sigma) was used for identifying the necrotic cells. Cells were treated with different concentrations of 1,3-BPMU $(0.001,0.1,0.2,0.5,1,2$, 5, 10, 20, 50 and $100 \mu \mathrm{g} / \mathrm{mL}$ ) for $48 \mathrm{~h}$, and then, experimental cells were harvested and resuspended in binding buffer (10 mM HEPES pH 7.4, $150 \mathrm{mM} \mathrm{NaCl}, 5 \mathrm{mM} \mathrm{KCl}, 1 \mathrm{mM} \mathrm{MgCl} 2$ and $1.8 \mathrm{mM} \mathrm{CaCl}_{2}$ ) containing FITC-annexin V $(1 \mu \mathrm{g} / \mathrm{mL})$ and incubated for $20 \mathrm{~min}$. About 10 minutes before the end of incubation, PI $(10 \mu \mathrm{g} / \mathrm{mL})$ was added to this cell suspension in order to stain necrotic cells. These cells were analyzed with a FACS flow cytometer (Becton Dickenson Biosciences, San Jose, CA, USA) equipped with an excitation laser line at $488 \mathrm{~nm}$. The PI was collected through a $575 \pm 15-\mathrm{nm}$ bandpass filter [38]. 


\subsection{Animals}

Male 150-170 g Wister albino rats (Rattus norvegicus) were selected for the experimental study. All rats were housed in polypropylene cages at $25 \pm 2{ }^{\circ} \mathrm{C}$ with $40 \%-55 \%$ relative humidity in dark and light conditions (each $12 \mathrm{~h}$ ). The rats were fed with normal feed and water ad libitum. The Institutional Animal Ethics Committee (743/03/abc/CPCSEA dt: 03.03.2003) and Committee for the Purpose of Control and Supervision of Experiments on Animals (CPCSEA, Chennai, India) approved the experiments.

\subsection{Experimental Design}

The rats were segregated into four groups each consisting of six animals. The experimental periods were 16 weeks as follows:

Group A: Normal rats fed with standard diet with ad libitum access to water.

Group B: Rats received 1,3-BPMU alone ( $50 \mathrm{mg} / \mathrm{kg} / \mathrm{bw} /$ day / orally based on the $\mathrm{IC}_{50}$ ) at 24-h intervals. Group C: Tumor control; hepatocarcinoma was induced by a single dose intraperitoneal (ip) injection of DEN $(200 \mathrm{mg} / \mathrm{kg} / \mathrm{bw})$, and further, rats were administered with phenobarbital (250 mg/kg/bw/day/orally for two weeks) as a cancer-promoting agent [39].

Group D: 1,3-BPMU-treated; hepatocarcinoma was induced by a single dose intraperitoneal (ip) injection of DEN (200 $\mathrm{mg} / \mathrm{kg} / \mathrm{bw})$; then, rats were administered with phenobarbital (250 $\mathrm{mg} / \mathrm{kg} / \mathrm{bw} /$ day/orally) for two weeks as a cancer-promoting agent; then, animals were treated with 1,3-BPMU (50 mg/ kg/bw/day/orally) up to the end of the experiment periods.

At the end of the experimental periods, the body weight was recorded, and then, rats were anesthetized with sodium pentothal. All rats were sacrificed by cervical dislocation. Liver samples were collected and weighed. A small portion of the liver was homogenized in $0.1 \mathrm{M}$ Tris buffer, $\mathrm{pH} 7.4$ and used for further assays. The visible size of the tumor was measured using a Vernier caliper, and the volume of the largest nodules was calculated [40].

\subsection{Analysis of Biochemical Parameters}

Tumor markers, such as $\alpha$-fetoprotein (AFP) and carcinoembryonic antigen (CEA), were quantified using a chemiluminescent immunoassay method. The activities of aspartate transaminase (AST), alanine transaminase (ALT), alkaline phosphatase (ALP), lactate dehydrogenase (LDH), superoxide dismutase (SOD), catalase (CAT), glutathione peroxidase (GPx), glutathione-S-transferase (GST), glutathione reductase (GR) $\gamma$-glutamyltransferase $\left(\gamma\right.$-GT), $5^{\prime}$-nucleotidase and levels of lipid peroxide (LPO), DNA and RNA were estimated [41-43].

\subsection{Expression of Genetic Analysis by qPCR (Caspse-3, Caspase-9, Bcl-2 and Bcl-XL)}

The RNA was extracted from experimental liver tissues using a commercial kit (RNA lipid tissue mini kit, Qiagen, Venlo, Netherlands) according to the manufacturer's protocol. The extracted RNA was estimated using a UVS-99 Micro-volume UV-VIS spectrophotometer (ACTGene, Piscataway, NJ, USA). One microgram of RNA was used to synthesize cDNA using oligo (dT) nucleotide and III reverse (superscript III first stand synthesis system-cDNA synthesis kit-Applied biosystems, Kookmin, Korea). The qPCR was conducted with an ABI 7500 Real-Time PCR System (Applied biosystems). Target gene expressions were determined by SYBR green-based real-time PCR in 20- $\mu \mathrm{L}$ reactions containing $10 \mu \mathrm{L}$ Power SYBR Green Master Mix (Applied Bio-Systems, Foster City, CA, USA), $1 \mu \mathrm{L}$ cDNA, $1 \mu \mathrm{L} 10$ pmole forward (FP) and reverse primers (RP). qPCR cycling protocol; polymerase activation $95^{\circ} \mathrm{C}, 3 \mathrm{~min}$; denaturation $95^{\circ} \mathrm{C}, 15 \mathrm{~s}$, annealing $58^{\circ} \mathrm{C}, 30 \mathrm{~s}$; Melting curve analysis $55-95^{\circ} \mathrm{C}$ with $0.5^{\circ} \mathrm{C}$ increment. caspase-3-FP: ATG TCG ATG CAG CTA ACC TC; RP: TCC TTT TGC TGT GAT CTT CC; caspase-9 FP: TCC TGC TTA GAG GAC ACA GG; RP: TGC TCC TTT GAT TTG AGT CC; Bcl-2 FP: GAC TCA CTA TAG GCG GGA GAT CGT G; RP: CAC TAT AGA GAA GGG CGT CAG 
GTG C; Bcl-XL FP: GAG CCA GAT CAT GTT TGA AGC CTT; RP: GGT GAC CGT AAC ACT ACC TGA G. $\beta$-actin FP: GACCCAGATCATGTTTAGGACCTT; RP: GGTGACCGTAACACTACCTGAG. The gene expression was normalized against the $\beta$-actin transcript signal.

\subsection{Caspase-3 Quantification}

The caspase-3 protein expression in experimental tissues was quantified by a commercial kit (ApoTarget, Invitrogen, Kookmin, Korea). Briefly, the tissues were resuspended in $50 \mu \mathrm{L}$ of cell lysis buffer and incubated on ice for $10 \mathrm{~min}$ and then centrifuged at $10,000 \times g$ for a min. The supernatant was collected; the protein concentration in each sample was estimated; an equal concentration of protein from each sample was taken; and $50 \mu \mathrm{L}$ of $2 \times$ reaction buffer and $5 \mu \mathrm{L}$ of $4 \mathrm{mM}$ DEVD-pNA substrate were added. Further, this was incubated at $37^{\circ} \mathrm{C}$ for $2 \mathrm{~h}$. Then, the absorbance of samples was measured at $400 \mathrm{~nm}$ using a microplate reader. The percentage of caspase- 3 expression was calculated from caspase- 2 in the normal control. Caspase- 3 in normal control cells was considered as $100 \%$.

\subsection{Histology and Ultra-Structural Investigation}

Two to three pieces of liver tissue, approximately $5 \mathrm{~mm}$ in size and fixed in $10 \%$ formalin solution and embedded in paraffin wax, were stained with hematoxylin-eosin $[44,45]$. The stained tissues were examined under the high-resolution microscope. For TEM analysis, the tissues were embedded in a mixture of (1:1) 1,2-epoxypropane and Epon (Epikote resin) and hardened using dodecyl succinic anhydride (DDSA) and methylnadic anhydride (MNA). Ultrathin sections were cut and stained with uranyl acetate and lead nitrate and collected on mesh grids coated with a thin Formvar film and viewed in an EM201C transmission electron microscope (Philips, Amsterdam, The Netherlands).

\subsection{Statistical Analysis}

Each experiment was carried out in replicates $(n=6)$. Data are expressed as the mean and the standard error of the mean (SEM). Statistical analysis was carried out using Excel (Microsoft, Washington, WA, USA) and one-way ANOVAs and multivariate comparisons using the Statistical Package for Social Science (SPSS) program Version 16.0 (SPSS, Inc., Chicago, IL, USA); significance was represented as $p<0.05$.

\section{Conclusions}

The Mannich base 1,3-BPMU exhibited significant cytotoxicity and cell growth inhibition in HEP-G2 hepatoma cells. In addition, it stimulated apoptosis in HEP-G2 hepatoma cells. Further, it reduced the nucleic acids, lipid peroxide, cancer marker proteins and the activities of pathophysiological liver markers and increased the antioxidant activities in DEN-induced rats, and 1,3-BPMU also stimulates apoptosis via upregulation of caspase-3 and caspase- 9 with downregulation of Bcl-2 and Bcl-XL gene expression. Histological and ultrastructural studies showed that 1,3-BPMU maintained the architecture of the liver in DEN-induced rats. This investigation suggested that 1,3-BPMU might be considered as a potent antitumor compound in the future. Further experiments are still needed to validate the molecular mechanism of action of 1,3-BPMU.

Acknowledgments: This study was supported by grants from the Cooperative Research Program for Agriculture Science \& Technology Development (Project No. PJ0113352016), Rural Development Administration, Korea. The authors extend their sincere appreciation to the Deanship of Scientific Research at King Saud University for its funding of this Prolific Research Group (PRG-1437-28) grant.

Author Contributions: Vadanasundari Vedarethinam, Ravikumar Sivanesan, Karthik Dhanaraj, Young Ock Kim, Ki Choon Choi, Han Sung Choi, designed and executed the experiments. Tamilvenvendan Dhanapal, Kyung Dong Lee, Da Hye Kim, Soundharrajan Ilavenil, Srigopalram Srisesharam analyzed the data and contributed for preparation of the manuscript. Mariadhas Valan Arasu., Naif Abdullah Al-Dhabi., contributed reagents/materials/analysis tools. 
Conflicts of Interest: The authors declare no conflict of interest.

\section{Abbreviations}

$\begin{array}{ll}\text { 1,3-BPMU: } & \text { 1,3-bis-[(3-hydroxy-naphthalen-2-yl)-phenyl-methyl]-urea } \\ \text { DEN: } & \text { Diethyl nitrosamine } \\ \text { HCC: } & \text { Hepatocarcinoma } \\ \text { AFP: } & \alpha \text {-fetoprotein } \\ \text { CEA: } & \text { Carcinoembryonic antigen } \\ \text { AST: } & \text { Aspartate transaminase } \\ \text { ALT: } & \text { Alanine transaminase } \\ \text { ALP: } & \text { Alkaline phosphatase } \\ \text { LDH: } & \text { Lactate dehydrogenase } \\ \text { LPO: } & \text { Lipid peroxide } \\ \text { SOD: } & \text { Superoxide dismutase } \\ \text { CAT: } & \text { Catalase } \\ \text { GPx: } & \text { Glutathione peroxidase } \\ \text { GST: } & \text { Glutathione-S-transferase } \\ \text { GR: } & \text { Glutathione reductase } \\ \gamma \text {-GT: } & \gamma \text {-glutamyl transferase }\end{array}$

\section{References}

1. Pascual, S.; Herrera, I.; Irurzun, L. New advances in hepatocellular carcinoma. World J. Hepatol. 2016, 28, 421-438. [CrossRef] [PubMed]

2. Bruix, J.; Sherman, M. Management of hepatocellular carcinoma. Hepatology 2005, 42, 1208-1236. [CrossRef] [PubMed]

3. Waghray, A.; Murali, A.R.; Menon, K.N. Hepatocellular carcinoma: From diagnosis to treatment. World J. Hepatol. 2015, 18, 1020-1029. [CrossRef] [PubMed]

4. Blonski, W.; Kotlyar, D.S.; Forde, K.A. Non-viral causes of hepatocellular carcinoma. World J. Gastroenterol. 2010, 16, 3603-3615. [CrossRef] [PubMed]

5. Aggarwal, B.B.; Shishodia, S. Molecular targets of dietary agents for prevention and therapy of cancer. Biochem. Pharmacol. 2006, 1, 1397-1421. [CrossRef] [PubMed]

6. Heindryckx, F.; Colle, I.; Van Vlierberghe, H. Experimental mouse models for hepato cellular carcinoma research. Int. J. Exp. Pathol. 2009, 90, 367-386. [CrossRef] [PubMed]

7. Ziech, D.; Franco, R.; Georgakilas, A.G.; Georgakila, S.; Malamou-Mitsi, V. The role of reactive oxygen species and oxidative stress in environmental carcinogenesis and biomarker development. Chem. Biol. Interact. 2010, 188, 334-339. [CrossRef] [PubMed]

8. Yeo, W.; Mok, T.S.; Zee, B.; Leung, T.W.; Lai, P.B.; Lau, W.Y.; Koh, J.; Mo, F.K.; Yu, S.C.; Chan, A.T.; et al. A Randomized Phase III Study of Doxorubicin versus Cisplatin/Interferon $\alpha-2 b$ /Doxorubicin/Fluorouracil (PIAF) Combination Chemotherapy for Unresectable Hepatocellular Carcinoma. J. Natl. Cancer Inst. 2005, 97, 1532-1538. [CrossRef] [PubMed]

9. Newman, D.J.; Cragg, G.M. Natural Products as Sources of New Drugs overthe 30 Years from 1981 to 2010. J. Nat. Prod. 2005, 75, 311-335. [CrossRef] [PubMed]

10. Kuntz, K.W.; Napper, M.L.; Hoveyda, A.H. Combinatorial catalyst discovery. Curr. Opin. Chem. Biol. 1999, 3, 313-319. [CrossRef]

11. Boucher, E.; Foner, A.; Reig, M.; Bruix, J. New drug for the treatment of hepatocellular carcinoma. Liver Int. 2009, 29, 148-158. [CrossRef] [PubMed]

12. Zhang, H.T.; Luo, H.; Wu, J.; Lan, L.B.; Fan, D.H.; Zhu, K.D.; Chen, X.Y.; Wen, M.; Liu, H.M. Galangin induces apoptosis of hepatocellular carcinoma cell via mitochondrial pathway. World J. Gastroenterol. 2010, 16, 3377-3384. [CrossRef] [PubMed]

13. Wang, S.W.; Pan, S.L.; Huang, Y.C.; Guh, J.H.; Chiang, P.C.; Huang, D.Y.; Kuo, S.C.; Lee, K.H.; Teng, C.M. CHM-1, a novel synthetic quinolone with potent and selective antimitotic antitumor activity against human hepatocellular carcinoma in vitro and in vivo. Mol. Cancer Ther. 2008, 7, 350-360. [CrossRef] [PubMed] 
14. Tamilvendan, D.; Rajeswari, S.; Ilavenil, S.; Chakkaravarthy, K.; Venkatesa, P.G. Synthesis, spectral, crystallographic, antimicrobial, and anti-oxidant studies of few mannich bases. Med. Chem. Res. 2012, 21, 4129-4138. [CrossRef]

15. Vadanasundari, V.; Ilavenil, S.; Ravikumar, S. Potential effect of bis-((hydroxyl-naphthalen-2-yl)phenylmethyl)-urea (1,3BPMU) on diethyl nitrosamine (DEN) induced hepatocarcinoma in wistar albino rats. Int. J. Pharm. Biol. Sci. 2014, 5, 364-372.

16. Le Couteur, D.G.; Warren, A.; Cogger, V.C.; Smedsrod, B.; Sorensen, K.K.; De Cabo, R.; Fraser, R.; McCuskey, R.S. Old Age and the Hepatic Sinusoid. Anat Rec. 2008, 291, 672-683. [CrossRef] [PubMed]

17. Wang, W.; Rayburn, E.R.; Velu, S.E.; Nadkarni, D.H.; Murugesan, S.; Zhang, R. In vitro and in vivo Anticancer Activity of Novel Synthetic Makaluvamine Analogues. Clin. Cancer Res. 2009, 15, 3511-3518. [CrossRef] [PubMed]

18. Tao, D.; Wu, J.; Feng, Y.; Qin, J.; Hu, J.; Gong, J. New method for the analysis of cell cycle-specific apoptosis. Cytom. Part 2004, 57, 70-74. [CrossRef] [PubMed]

19. Vina, J.; Gomez-Cabrera, M.C.; Lloret, A.; Marquez, R.; Minana, J.B.; Pallardo, F.V.; Sastre, J. Free radicals in exhaustive physical exercise: Mechanism of production, and protection by antioxidants. IUBMB Life 2000, 50, 271-277. [CrossRef] [PubMed]

20. Tayob, N.; Lok, A.S.; Do, K.A.; Feng, Z. Improved detection of hepatocellular carcinoma using a longitudinal $\alpha$-fetoprotein screening algorithm. Clin. Gastroenterol. Hepatol. 2016, 14, 469-475. [CrossRef] [PubMed]

21. Rich, N.; Singal, A.G. Hepatocellular carcinoma tumor markers: Current role and expectations. Best Pract. Res. Clin. Gastroenterol. 2014, 28, 843-853. [CrossRef] [PubMed]

22. Morrison, C.; Marsh, W., Jr.; Frankel, W.L. A comparison of CD10 to pCEA, MOC-31, and hepatocyte for the distinction of malignant tumors in the liver. Mod. Pathol. 2002, 12, 1279-1287. [CrossRef] [PubMed]

23. Arrieta, O.; Cacho, B.; Morales-Espinosa, D.; Ruelas-Villavicencio, A.; Flores-Estrada, D.; Hernandez-Pedro, N. The progressive elevation of $\alpha$-fetoprotein for the diagnosis of hepatocellular carcinoma in patients with liver cirrhosis. BMC Cancer 2007, 7, 28. [CrossRef] [PubMed]

24. Liu, C.C.; Yang, H.; Zhang, R.; Zhao, J.J.; Hao, D.J. Tumor-associated antigens and their anti-cancer applications. Eur. J. Cancer Care (Engl.) 2016. [CrossRef] [PubMed]

25. Park, E.J.; Jeon, C.H.; Ko, G.; Kim, J.; Sohn, D.H. Protective effect of curcumin in rat liver injury induced by carbon tetrachloride. J. Pharm. Pharmacol. 2000, 52, 437-440. [CrossRef] [PubMed]

26. Nguyen, M.H.; Keeffe, E.B.; Frederiks, W.M.; Van Noorden, C.J.; Aronson, D.C.; Marx, F.; Bosch, K.S.; Jonges, G.N.; Vogels, I.M.; James, J. Quantitative changes in acid phosphatase, alkaline phosphatase and 5'nucleodidase activity in rat liver after experimentally induced cholestasis. Liver 1990, 10, 158-166.

27. Kamdem, L.; Siest, G.; Magdalou, J. Differential toxicity of aflotoxin B1 in male and female rats' relationship with hepatic drug metabolizing enzymes. Biochem. Pharmacol. 1982, 31, 3057-3062. [CrossRef]

28. Esterbauer, H.; Chessman, K.H. Determination of aldehydic lipid peroxidation products: Malonoldehyde and 4-hydroxy-nonenal. Methods Enzymol. 1990, 186, 407-421. [PubMed]

29. Revathi, R.; Manju, V. Effects of umbelliferone on lipid peroxidation and antioxidant status in diethylnitrosamine-induced hepatocellular carcinoma. J. Acute Med. 2013, 3, 73-82.

30. Jiang, B.; Xiao, W.; Shi, Y.; Liu, M.; Xiao, X. Heat shock pretreatment inhibited the release of Smac/DIABLO from mitochondria and apoptosis induced by hydrogen peroxide in cardiomyocytes and $\mathrm{C}_{2} \mathrm{C}_{12}$ myogenic cells. Cell Stress Chaperones. 2005, 10, 252-262. [CrossRef] [PubMed]

31. Klaunig, J.F.; Kamendulis, L.M. The role of oxidative stress in carcinogenesis. Ann. Rev. Pharmacol. Toxicol. 2004, 44, 239-267. [CrossRef] [PubMed]

32. Ryter, S.W.; Kim, H.P.; Hoetzel, A.; Park, J.W.; Nakahira, K. Mechanisms of cell death in oxidative stress. Antioxid. Redox Signal. 2007, 9, 49-89. [CrossRef] [PubMed]

33. Ozen, T.; Korkmaz, H. Modulatory effect of Urtica dioica L (Urticaceae) leaf extraction biotransformation of enzyme systems, antioxidant enzymes, and LDH and lipid peroxidation in mice. Phytomedicine 2003, 10, 405-415. [CrossRef] [PubMed]

34. Riedl, S.J.; Shi, Y. Molecular mechanisms of caspase regulation during apoptosis. Nat. Rev. Mol. Cell Biol. 2004, 5, 897-907. [CrossRef] [PubMed]

35. Earnshaw, W.C.; Martins, L.M.; Kaufmann, S.H. Mammalian caspases: Structure, activation, substrates, and functions during apoptosis. Ann. Rev. Biochem. 1999, 68, 383-424. [CrossRef] [PubMed] 
36. Vadanasundari, V.; Karthik, D.; Ilavenil, S.; Ravikumar, S. Identification of Differential Protein Expression in Hepatocellular Carcinoma Induced Wistar Albino Rats by 2D Electrophoresis and MALDI-TOF-MS Analysis. Indian J. Clin. Biochem. 2015. [CrossRef]

37. Tavakoli, M.; Fatemeh, Y.; Tehrani, K. Apoptosis Induced by 13-S-hydroxy octadecadienoic acid in the breast cancer cell lines, MCF-7 and MDA-MB-231. Iran. J. Basic Med. Sci. 2013, 16, 661-669.

38. Su, N.W.; Lin, Y.L.; Lee, M.H.; Ho, C.Y. Ankaflavin from Monascus-fermented red rice exhibits selective cytotoxic effect and induces cell death on Hep G2 cells. J. Agric. Food Chem. 2005, 53, 1949-1954. [CrossRef] [PubMed]

39. Peraino, C.; Fry, R. J.M.; Staffeldt, E. Reduction and enhancement by phenobarbital of hepatocarcinogenesis inducedin the rat by 2-acetylaminofluorene. Cancer Res. 1971, 31, 1506-1512.

40. Bishayee, A.; Dhir, N. Resveratrol-mediated chemoprevention of diethy lnitro samine-initiated hepatocarcinogenesis: Inhibition of cell proliferation and induction of apoptosis. Chem. Biol. Interact. 2009, 179, 131-144. [CrossRef] [PubMed]

41. Stuhr, L.E.; Iversen, V.V.; Straume, O.; Maehle, B.O.; Reed, R.K. Hyperbaric oxygen alone or combined with 5-FU attenuates growth of DMBA-induced rat mammary tumors. Cancer Lett. 2004, 210, 35-40. [CrossRef] [PubMed]

42. Sivaramakrishnan, V.; Shilpa, P.N.; Praveenkumar, V.R.; Niranjali devaraj, S. Attenuation of $\mathrm{N}$-nitrodiethylamine-induced hepatocellular carcinogenesis by a noval flavonol-Morin. Chem. Biol. Interact. 2008, 171, 79-88. [CrossRef] [PubMed]

43. Karthik, D.; Ravikumar, S. Proteome and phytochemical analysis of Cynodon dactylon leaves extract and its biological activity in diabetic rats. Biomed. Prev. Nutr. 2011, 1, 49-56. [CrossRef]

44. Graham, L.; Orenstein, J.M. Processing tissue and cells for transmission electron microscopy in diagnostic pathology and research. Nat. Protocol. 2007, 2, 2439-2450. [CrossRef] [PubMed]

45. Cogger, V.C.; Mross, P.E.; Hosie, M.J.; Ansselin, A.D.; McLean, A.J.; Le Couteur, D.G. The effect of acute oxidative stress on the ultra-structure of the perfused rat liver. Pharmacol. Toxicol. 2001, 89, 306-311. [CrossRef] [PubMed]

Sample Availability: Samples of the compounds are available from the authors.

(c) 2016 by the authors; licensee MDPI, Basel, Switzerland. This article is an open access article distributed under the terms and conditions of the Creative Commons Attribution (CC-BY) license (http://creativecommons.org/licenses/by/4.0/). 